Article

\title{
From Contextual Theology to African Christianity: The Consideration of Adiaphora from a South African Perspective
}

\author{
Joel Mokhoathi \\ Faculty of Theology and Religion, Department of Religion Studies, University of the Free State, \\ Bloemfontein 9301, South Africa; Mokhoathij@ufs.ac.za
}

Received: 7 November 2017; Accepted: 6 December 2017; Published: 8 December 2017

\begin{abstract}
The move towards contextual Christianity in Africa is an essential venture if Christianity is to communicate with the African cultural heritage. As a universal religion, Christianity has to find an expression within the cultural context. However, the contextualization of Christianity in Africa appears to have permitted the practice of syncretism. It has resulted in the emergence of African Christianity, which is the amalgamation of Christianity and African Traditional Religion. The amalgamation of Christianity and African Traditional Religion appears to overlook the essence of both religions as there is currently no clarity on how Christianity can best be expressed within the African cultural and religious heritage. This paper employs the document review method to explore the things that fall in between - "adiaphora", which the proponents of contextual Christianity may have overlooked with regard to the African cultural and religious heritage. These include the pragmatic nature of the African cultural and religious heritage, and the African traditional methods of healing.
\end{abstract}

Keywords: contextualization; African Christianity; African Traditional Religion; African cultural and religious heritage

There is an eminent move towards contextual Christianity in African scholarship. A great number of African scholars contend for the contextualization of Christianity, which aims at providing a link between the African cultural and Christian underpinnings. But what seems to be lacking in this debate is the critical evaluation of how Christianity can fully be expressed or practiced within the cultural context. Even though it is apparent that Africans yawn to experience Christianity within their cultural setting, it still remains to be established how Christianity can best be communicated within an African cultural context. So far, the contextualization of Christianity seems to have permitted syncretism. It has resulted in the emergence of "African Christianity", which is the amalgamation of Christianity and African Traditional Religion (ATR). The amalgamation of Christianity and African Traditional Religion appears to overlook the essence of both religions, as the elements of one religion are expressed through the other. In this paper, I argue that there are "things in between"-Adiaphora, which the proponents of contextual Christianity seem to have overlooked with regard to the African cultural and religious heritage. These include the pragmatic nature of the African cultural and religious heritage; and African traditional methods of healing.

Within the modern missiological debate, there are scholars who contend that the attitude of early missionaries towards the African cultural and religious heritage was often misguided (Fiedler 1996; Mugambi 2002; Sanou 2013). Early missionaries are accused of being too much involved with their own culture (colonialism included), did not understand much of the African culture, and worked hard to destroy what they did not understand (Fiedler 1996, p. xi; Mokhoathi 2017, p. 2f; Sanou 2013, p. 7). This error, according to Mugambi (2002, p. 520), resulted in the perception of the Christian identity as 
equivalent to the western cultural and religious heritage. Following western precedence, conversion was determined by behavioural norms, in which African converts had to abandon their traditional African customs and adopt the western ones (Oduro et al. 2008, p. 37).

In that context, African converts were forced to live double lives (Mugambi 2002; Oduro et al. 2008). Mugambi depicts this dichotomy in the following manner:

On the one hand, they accepted the norms introduced by the missionaries who saw nothing valuable in African culture. On the other hand, the converts could not deny their own cultural identity. They could not substitute their denominational belonging for their cultural and religious heritage. Yet they could not become Europeans or Americans merely by adopting some aspects of the missionaries' outward norms of conduct. (Mugambi 2002, pp. 519-20)

The strain of having to live by double standards for African converts brought about some difficulties in the appreciation of the Christian identity. The principal concern was: "What should be the proper relationship between Christian identity and a Christian's cultural identity?" (Mugambi 2002, p. 520). As expected, there were no simple answers to this enquiry. But suggestions towards the consideration of inculturation (Magesa 2004; Mbiti 1975; Bujo 2003) ${ }^{1}$; the reformation or reconstruction of Christianity in Africa (Mugambi 1995; Shorter 1975); and the Africanisation of Christianity, seemed to be more favourable (Oden 2007; Van der Merwe 2016; Akao 2002).

All these approaches sought to make Christianity more communicative with the African cultural and religious heritage (Bediako 1994, p. 15; Fasholé-Luke 1975, p. 267). In this regard, Oden (2007, p. 93) argues that " $[\mathrm{m}]$ any African Christians today have a deep conviction that they must think in terms that are indigenously African because this is what has been most neglected". This deep seated conviction, which tends to lean back to African forms of thought and expression, has become the premise and a solid foundation of African theology (Nwibo 2010, p. 36; Mbiti 1977, p. 83). African theology is the embodiment of the contextualization of Christianity. Muzorewa attests that African theology is an "attempt to respond to a mandate to construct a biblically-based and relevant theology that speaks to the spiritual needs of the African people" (Muzorewa 1985, p. 96). Thus, the goal of African theology ${ }^{2}$ is to construct a biblically-based and relevant theology that can meet the spiritual needs of African people.

The implications therefore, of African theology, are that imported theologies do not sufficiently touch the hearts of African believers because they are couched in a language that is foreign to them (Muzorewa 1985, pp. 96-97). And, that the building of communication between Christianity and the African cultural and religious heritage is best left for African theologians because they know how best to contextualize Christianity in a manner that can fully communicate with their African cultural and religious heritage (Muzorewa 1985). Thus, in this argument, Christianity needs to assume a local and Africanised temperament, where it can be communicated in a language that Africans can understand and appreciate; and be articulated in a manner that can touch the hearts of Africans. In its reproduction, it is exclusively the task of African theologians to contextualize Christianity so that it may fully communicate with the African cultural context. As to how this can be done, it is not clear. But what is apparent is that the contextualization of Christianity has resulted in the emergence of African Christianity.

1 Tinyiko Maluleke (Maluleke 2005, p. 477) alludes to the urgency at which Africans sought to make Christianity communicate with their African cultural context. He notes that "from various fronts, African Christians insisted that the church of Africa and its theology must bear an African stamp". In his view, this insistence moved beyond theological and ecclesiastical matters as other African thinkers also attempted to construct "African philosophy", "African literature", "African art", and "African architecture".

2 It is worth noting that some African scholars draw distinctions between "African theology" and "Black theology", while others see the two concepts as interconnected. Manas Buthelezi (Buthelezi 1986, p. 220), for instance, seems to favour the notion of "Black theology" more than that of "African theology"; while Desmond Tutu (Tutu 1986, p. 262) regards both "African theology" and "Black theology" as soulmates (cf. Motlhabi 1994, pp. 113-41). 
The term "Christian", in this paper, is used to refer to "a person who has accepted the Christian faith and made a firm decision to become a follower of Jesus Christ." (Mugambi 2002, pp. 516-17). In consequent, "Christianity" is regarded as an institute which affirms the Lordship of Jesus Christ, as the Son of God, who brings about the process of reconciliation between humanity and God (Barker 2005, p. 2). Against this background, Christianity is taken to be a "non-cultural entity", which only finds a sense of expression within a cultural medium (Mugambi 2002, p. 516). On this ideal, Mugambi (2002, p. 517) employs an analogy to epitomise how Christianity floats with different cultures: "One missionary scholar liked the Christian faith to a jockey who rides a racing horse as long as the horse is a faster runner. When the horse loses its racing ability, the jockey chooses another horse, and by so doing he remains on the racecourse".

Giving his own interpretation to this analogy, Mugambi (2002, pp. 517-18) further asserts that:

Christianity began within the Jewish culture. That culture became incapable of sustaining the Christian faith because the leaders of Judaism believed that the new faith was a threat to the Jewish culture [ ... ]. Then it was greatly influenced by Greek philosophy, without being swallowed by it. In the fourth century Christianity became the popular religion of the Roman Empire, after the conversion of Emperor Constantine [ . . . ]. During the modern missionary enterprise Christianity was riding on western culture.

This analogy, therefore, seems to qualify the scholastic language of speaking of Christianity as having arrived in Africa as part of the Western campaign of civilization, which was meant to redeem the 'Dark Continent' from the claws of ignorance and devilish superstitions (Bediako 1992, p. 225; Bosch 1991, pp. 227, 312-13). In this narrative, Christianity was equated to western culture, hence the need for African Christianity arose.

African Christianity is the amalgamation of Christianity and African Traditional Religion (Maluleke 2010, p. 370; Mndende 2013, p. 79). It is a form of Christianity that draws from both the Christian faith and African Traditional Religion for some ethico-spiritual principles. It is evidenced by the reverting of Christians back to African traditional practices and the consultation of traditional healers ${ }^{3}$. In this narrative, it becomes difficult for Africans to plainly choose between Christianity and their African traditional practices. Christianity connects them to God while African traditional practices provide a lasting bond with their ancestors. In such a situation, they tend to lack the aspiration to part ways with Christianity and to totally abandon the ATR. According to Mbiti (1969, p. 223), the other reason why Africans cannot simply choose between Christianity and ATR is that Christianity has been in existence for a very long time in Africa. It has influenced the lives of Africans for so long that "it can rightly be described as an indigenous, traditional and African religion" (Mbiti 1969, p. 223).

The term "African Traditional Religion (ATR)", in this paper, assumes a singular connotation. This stands against the popular perception that, as an umbrella term for various African religions, the term should be used in plural (Mndende 2013, pp. 76-77). African scholars like Mbiti (1990, pp. 1-5) initially followed this direction, as he referred to "ATR" in plural (as African religions). He used the term in this manner to account for the different beliefs and traditions that are found in African ethnic groups (Adamo 2011, p. 5). However, Mbiti (1990, p. 13) later revised his position on the second edition: "in the first edition I spoke about "African religions" in the plural to keep alive the diversity of African religiosity [ ... ]. I now use the singular, "African religion," more than the plural expression".

The word "traditional" is included "to indicate that these religions emerged among traditional communities in specific regions before they came into contact with other world religions and cultures" (Crafford 2015, p. 2). Thus, the use of "ATR" in the singular is perceived to be more approving because it accounts for the common racial origin of Africans and the similarities of their culture and religious

3 Traditional healers do not perform the same functions, nor do they fall into the same category but each traditional healer has a field of expertise, with their own methods of diagnosis and a particular set of knowledge in traditional medicines (cf. Ilse Truter 2007, pp. 57-58). 
beliefs (Idowu 1973, pp. 103-4). Shorter $(1975$, p. 1) further asserts that the "ATR" should be spoken of in the singular because of the basic unity of African religious systems:

Although they (African religious systems) were separate and self contained systems, they interact with one another and influenced one another to different degrees. This justifies our using the term African Traditional Religion in the singular to refer to the whole African religious phenomena, even if we are, in fact, dealing with multiplicity of theologies.

Thus, the common racial origin of Africans and the similarities in their culture and beliefs, deems it appropriate to conceive of the ATR in the singular rather than in plural.

Due to the amalgamation of Christianity and ATR, a different form of Christianity has emerged in Africa. It is African Christianity. Since its emergence, scholars like Maluleke (2010, p. 370) noted that "[t]he very notion of "African Christianity" appeared to depict something to be handled with caution and suspicion, if it was not to be rejected altogether". This is because the very concept of "African Christianity" lacked the requisite history, culture and theological traditions for Christianity to take on a distinguishable African identity, and the suggestion that Christianity was universal and therefore did not need to be qualified as "African" (Maluleke 2010, p. 370). This implies that the concept of "African Christianity" was, to begin with, uncalled for.

African Christianity does not have the necessary history, the cultural backing or theological traditions that may distinctively give it an "African" identity. Furthermore, as a universal religion, Christianity cannot simply be reduced to an "African" concept. This may lower the "universal standards" of Christianity and fit it with the local "African standards" (Maluleke 2010, p. 372). Thus, the concept of "African Christianity" remains a point of contention in African scholarship. Maluleke (2010, p. 372) further notes that the notion of "African Christianity" is too wide and covers a great scope to be meaningfully examined. But in an effort to signify the nature and temperament of Christianity when amalgamated with ATR, which in turn produces a new form of Christianity-"African Christianity", Mndende (2013, p. 79) used the following diagram (Figure 1):

The above diagram (Figure 1) shows that "African Christianity" is a result of the amalgamation of Christianity and ATR. It is the product of syncretism, from which the ethico-spiritual principles of Christianity are practiced in conjunction with those of the ATR. From an outsider's view, the amalgamation of Christianity and ATR appears to dilute the purity of Christianity or that of the ATR, as both religions seem to lose their uniqueness when expressed with the other (Bediako 1994, p. 14; Hastings 1989, pp. 30-35). This form of expression therefore, may easily be interpreted as the distortion of the originality of both systems, since there is presently no definite clarity on how both systems come or work together (Hastings 1989). Adamo (2011, p. 16) further notes that many Christian theologians consider the dialogue between Christianity and ATR to be a step towards syncretism.

He expresses this idea in the following manner: "In fact, the question of inculturation or Africanisation of Christianity is seen as a corruption of Christianity, because Christianity must be Christocentric. As a result, (the) Christian religion is absolutised" (Adamo 2011, p. 16). McGuire (2008, p. 189) traces the hesitation of blending Christianity with other religions from the era of the Reformation. She asserts that " $[\mathrm{t}$ ]oward the end of the Long Reformation, theologians gave the term "syncretism" a pejorative connotation: It came to mean the blending of foreign, non-Christian elements with (putatively "pure", "authentic") Christian beliefs and practices" (McGuire 2008, p. 189). In that sense, syncretism was regarded as the corruption of the Christian faith.

Contrary to this, anthropologists such as Stewart (1994, p. 274) argue for the move beyond "syncretism" to "hybridity". Shaw and Stewart (1994, p. 26) further states that syncretism is "the process by which cultures constitute themselves at any given point", and McGuire (2008, p. 190) notes that "[a]ll cultural traditions-including religious traditions-are based on this kind of inter-penetration and interaction with external influences". This seems to suggest that "all religions are necessarily syncretic and continually changing, as people try to make sense of their changing social worlds, including other cultures with which they come in contact" (McGuire 2008, p. 192). 
This, probably, warrants the review of the referral of African Christianity, which is, indeed, the amalgamation of Christianity and ATR, as "syncretism". As Oden $(2007$, p. 93) argued, "Christianity meets the criterion of indigenous or traditional African religion, since it has twenty centuries of sustained presence in Africa".

However, due to the lack of clarity on how Christianity can best be practiced within the African cultural and religious heritage, there is a developed sense of realisation that Christianity in Africa is syncretised with traditional practices (Jebadu 2007, p. 246; Onuzulike 2008, p. 6; Mndende 2009, p. 1). Some research studies conducted in this field indicates that the nature of Christianity that is commonly practiced by Africans is dichotomous-it is the combination of Christianity and ATR (Ntombana 2015, p. 106; Amanze 2003, p. 43; Matobo et al. 2009, p. 105). The amalgamation of these two traditions therefore, has raised some concerns for some Christian institutions. The Pastoral statement of the Southern African Catholic Bishops (2006, p. 1), for instance, states that there are Catholic Christians who search for healing from Sangomas ${ }^{4}$. The Pastoral statement further notes that some priests go so far as to "act as Sangomas" by calling upon the ancestors for healing (Southern African Catholic Bishops 2006, p. 1).



Figure 1. The nature of African Christianity. Source: Mndende (2013). Law and Religion in South Africa: An African Traditional Perspective.

Scholars such as Ntombana (2015, p. 105) also notes that there are professed Christians within the Mainline or Mission Churches, who tend to revert to African traditional practices or consult traditional healers for healing. The falling back of Christians to African traditional practices appears to be a developed phenomenon in Africa. What makes this phenomenon even more disquieting is that there are priests or pastors who go over-board to becoming traditional healers, while professing to be 'bona fide' Christians. To this, scholars such as Mlisa $(2009$, p. 8$)$ argue that "it is no longer a shame to see a well-educated person or Christian in igqirha's (diviner) regalia or wearing white beads both at church and at work". The acceptance of syncretism, by African Christians, has become a practical realism in South Africa.

This is largely a result of the contextualization of Christianity in Africa, it opened doors for syncretism. The main concern with the contextualization of Christianity in Africa is that African scholars did not attend to the consideration of adiaphora. They have mainly focused on the positive and negative aspects of the African cultural heritage. They tend to elevate the positive and reject the negative (Lado 2006, p. 11). The positive aspects include practices such as hospitality, humaneness (Ubuntu), respect—of God, of life, of ancestors, of elders or of nature, etc. These are highly encouraged (Mbiti 1969; Bujo 2003; Futhwa 2011). The negative aspects include practices such as witchcraft, stealing, killing, human sacrifices, disregarding ancestors, interfering with community life, etc. These

4 A Sangoma or diviner is the most senior of the traditional healers. She or he is a person who defines an illness (diagnostician) and also divines the circumstances of the illness in the cultural context. Diviners are known by different names. For example, they are known as Igqirha in Xhosa, Ngaka in Northern Sotho, Selaoli in Southern Sotho, and Mungome in Venda and Tsonga. But most South Africans generally refer to them as Sangomas-from the Zulu word Izangoma (cf. IIse Truter 2007, p. 57). 
are firmly discouraged (Magesa 1998; Awolalu 1976; Awolalu and Dopomu 1979). In this sense, the contextualization of Christianity in Africa appears to have been mainly concerned with the integration of positive aspects of the African cultural heritage into the Christian faith (Lado 2006, p. 11). This is at the exclusion of those things that fall "in between". I refer to these as "adiaphora".

Since the contextualization of Christianity in Africa has mainly focused on the integration of positive aspects of the African cultural heritage into the Christian faith, it appears to have overlooked the two influential components of the African cultural and religious heritage. These are, namely: the pragmatic nature of the African cultural and religious heritage; and the traditional methods of healing. These are what calls for the consideration of "things in between (adiaphora)". By this, I suggest that the contextualization of Christianity in Africa should not only consider the positive or negative aspects of the African cultural and religious heritage, but should also take into account the nature of such a cultural and religious heritage. This is because the cultural and religious heritage of many Africans serves as their worldview - that is, the way they see the world, understand wellness and get to maintain balance in their lives.

This worldview is complete, not dichotomous. It encompasses both the positive and negative, and those things that fall "in-between". Its wholeness therefore, calls for the consideration of adiaphora, especially when it comes to the contextualisation of Christianity. The term "adiaphora", in biblical terms, refers to "disputable matters" (1 Corinthians 8 vs. 4-7). St. Paul, for example, employs this concept to address the liberty of conscience. He notes that one can eat food sacrificed to idols, but it should not be in the presence of a believer with a weaker conscience ${ }^{5}$. In this sense, the notion of "adiaphora" is evoked. St. Paul appears to be suggesting that eating food sacrificed for idols is "debatable"-if there is no one who may be harmed by it, it is permissible; but if the conscience of a weaker believer may be harmed, it is discouraged. This applies both ways-there is no apparent sense of right and wrong.

But in this paper, "adiaphora" denotes "indifferent things" (Evans 2009, p. 23). This suggests that the term clearly encapsulates the nature of the African cultural and religious heritage. It is something that cannot be sensibly differentiated. This is because the elements of culture are closely aligned to those of the religious heritage. In that sense, it is difficult to separate the cultural from the religious heritage. They are both intertwined. This entails that when an African convert becomes a Christian, they carry both their cultural and religious heritage with them, and these are often incorporated to their new Christian way of life. But as research has shown, this process tends to produce the assimilation of dual identities (Mugambi 2002, pp. 519-20). This is mainly because African converts do not know how to express their Christian faith within their cultural context. They ultimately resolve to blend Christianity with African traditional practices.

In this impression, Christianity finds it difficult to absorb the entire richness of the African cultural and religious heritage, and to transform the intricate aspects of that cultural and religious heritage which do not match with its ideals. In this sense, some African traditional practices, which are neither seen as positive nor negative, such as the ritual reincorporation of the living-dead (ukubuyisa), the ritual inclusion of babies into the clan (pitiki), the rite of passage into manhood (lebollo), or the consultation of traditional healers, are allowed to form part of this Christian identity. ${ }^{6}$ These traditional practices form part of the African cultural and religious heritage, and are neither seen as positive nor negative. Instead, they assume a neutral position.

For the reason that these traditional practices are perceived as neutral, one cannot tell whether they are part of the cultural or religious heritage. They fall on both sides. In this sense, they cannot

5 For further discussions on this matter (cf. Carson 2015, pp. 385-56).

6 African Independent or Initiated Churches (AICs), for instance, have taken a firm and decisive position on the inclusion of African traditional rituals into their Christian system. In most AICs, there is no apparent contradictions in the practice of African traditional rituals, which include the veneration of ancestors, with one being a committed Christian (cf. Ntombana 2015, pp. 106-7). 
simply be disregarded as negative ${ }^{7}$. Their status is neutral. What appears to disquiet many institutions, however, about this situation, is that many professed Christians tend to substitute Christianity and its principles with African traditional practices. They often search for answers or immediate interventions outside the bounds of the Church (Ntombana 2015, p. 108), and tend to pretend as if the church is sufficiently meeting or catering for their needs. In such a predicament, many African believers claim to be "bona fide" Christians while supporters of ATR in private (Mndende 2009, p. 8).

As a pragmatic system, the ATR contains a set of beliefs and ritual practices that promise immediate returns, whereas mainstream Christianity largely insists on faith and hope (Lado 2006, p. 18; Hammond-Tooke 1974, p. 318). Therefore, when moments of crises occur within the Christian setting, believers are often encouraged to pray (or are prayed for) and advised to patiently wait for God's intervention. Scriptural readings like James 1 (verses 2 and 3) seems to suggest that the occurrence of "trials" and "suffering" in a believer's life equals the test of character, which in turn develops one's faith and the level of perseverance ${ }^{8}$. In this setting, faith and hope are prominent features. An alternative to mainstream Christianity and its methods of healing, is the use of conventional medicines.

These are commonly known as western medicines. Truter, for instance, notes that conventional medicines are usually associated with curing diseases of the physical body, and are based on the principles of science, technology, knowledge and clinical analysis which are developed in Northern America and Western Europe (Truter 2007, p. 57). These mainly focus on the physical, emotional, psychological, and social aspects of individuals, families and communities but tend to ignore the spiritual. Traditional medicines" ${ }^{9}$, on the other hand, are said to be "intertwined with cultural and religious beliefs", and are "holistic in nature". In this sense, they do not only focus on the physical, emotional, psychological, and social aspects of the individuals, families and communities, but also cater for spiritual conditions (Truter 2007, p. 57). Traditional medicines therefore, seem to be mostly favoured by Africans.

The pragmatic nature of traditional beliefs and ritual practices therefore, seem to underpin the manner in which African people attend to pressing matters. Because they obtain immediate returns from them, many professed Christians tend to revert back to African traditional practices for worrying socio-spiritual issues. This is because Mainstream Christianity lacks this attitude. An exception can be found with Pentecostal and Charismatic Churches. Commenting on the foundations of Christian villages, by missionaries around the nineteenth century, Isichei $(1995$, p. 199) notes that it was "no coincidence that a number of Christian prophetic movements were founded during the $1918 \mathrm{flu}$ pandemic, which made the limitations of both western and traditional medicines painfully apparent".

Thus, Pentecostal and Charismatic Churches possess a form of pragmatism which appears to compete with mainstream Christianity ${ }^{10}$ and ATR. To this, Anderson (2000, p. 66) notes that African Pentecostal Churches proclaim a message of deliverance from sickness and from oppression of evil spirits, and the message of receiving the power of the Holy Spirit, which enables people to survive in a predominantly hostile traditional spirit world. In this sense, African Pentecostal and Charismatic Churches become an attractive religion that offers solutions to all problems of life, and not just the spiritual ones (Anderson 2000, p. 66). This is what is lacking in mainstream Christianity, hence many professed Christians tend to revert back to African traditional practices.

7 Wallace Mills (Mills 1995, pp. 153-72), however, notes that missionaries rejected the practice of traditional rites and customs. Among the Xhosas, for instance, traditional rites and customs such as circumcision (initiation rites), lobola (dowry, or bride-price), the drinking of traditional beer, etc. were opposed by missionaries.

8 James 1 vs. 2-3 reads as follows: “Consider it pure joy, my brothers, whenever you face trials of many kinds, because you know that the testing of your faith develops perseverance" (NIV translation).

9 According to Richter (2003), the WHO Centre for Health Development defines African traditional medicines as "the sum total of all knowledge and practices, whether explicable or not, used in diagnosis, prevention and elimination of physical, mental, or societal imbalance, and relying exclusively on practical experience and observation handed down from generation to generation, whether verbally or in writing".

10 Mainstream Christianity, in this paper, refers to those Christian churches that follow the Nicene Creed and include the Roman Catholic Church, Eastern Orthodox, Anglican and major Protestant churches (cf. The New Encyclopaedia Britannica 2007). 
Within the African traditional setting, when people are overwhelmed by crises, they are encouraged to consult traditional healers, prophets or seers (Mogoba 2011, p. 176; Hammond-Tooke 1974, p. 318). These promise immediate returns. In that manner, the Christian principles of faith and hope are often abandoned for traditional interventions. This is a process which seems to suggest that "pressing matters need immediate interventions", since African converts look for quick answers from traditional healers. Furthermore, this appears to create disparity in the church as a system that requires the exercise of patience is constantly compared against or substituted by a fast-paced system, which promises immediate returns. By leaning back to African traditional practices, believers substitute Christian principles for traditional interventions.

Due to the lack of clarity on how Christianity can best be expressed within the African cultural and religious context, scholars are divided in their understanding of this matter. There are currently three guiding perspectives regarding the amalgamation of Christianity and African Traditional Religion. The first is that of conservative Christians. In this perspective, Christian scholars like Jarvis (2009, p. 43) argue that Christianity does not permit the inclusion of African cultural and religious beliefs that conflict with the revelation of God as found in the Bible. Therefore, African Christians must renounce and break away from these cultural and religious beliefs. In this sense, African Christians are encouraged to renounce their traditional cultures and religious beliefs that pertain to the "fear of evil spirits, evil spells, curses, or the anger or favour of spirits of ancestors" (Jarvis 2009, p. 44) ${ }^{11}$.

The second is the African rigorist perspective. This is the perspective that seeks to preserve the African cultural and religious heritage of indigenous people, which was handed down by the forebears of the present generation (Mbiti 1975, p. 12). Within this perspective, scholars like Mndende argue that Africans must not mix their African Traditional Religion with other religions such as Christianity or Islam. The amalgamation of African Traditional Religion with other faiths like Christianity or Islam is interpreted, by Mndende (2009, p. 1), to be the constraint of 'true' African spirituality. In this sense, the perspective maintains that indigenous people should preserve their African Traditional Religion and not mix their African traditional cultures and religious practices with Christian or Islamic elements. Those who amalgamate the African Traditional Religion with Christianity or Islam, are said to be "sitting on the fence" (Mndende 2009, p. 1).

The third and last perspective is that of moderate African religionists. This perspective assumes a middle ground. It argues that both Christianity and African Traditional Religion can be amalgamated or made to work together (Mlisa 2009, p. 9; Hirst 2005, p. 4). This is because Christianity has strongly influenced the Africans to an extent that they have to integrate Christian values into their cultural value systems (Mbiti 1975, p. 14). Within this perspective, Christianity is the means by which African Christians get to relate with God, while African traditional practices provide some form of socio-spiritual context which connects them to their ancestors (Mbiti 1992, p. 264). In this sense, Christianity and ATR are understood to be related systems of thought and practice.

The rationale for the positions taken by both conservative Christians, and African rigorist religionists appears to be reasonable. Both Christianity and African Traditional Religion seek to preserve some form of purity by waning off any signs of religious infiltration into their distinctive beliefs. In this context, both the conservative Christian and African rigorist perspectives, seem to assume a protective position. They both seeks to keep syncretism away from their distinctive faiths. However, the manner in which both Christianity and African Traditional Religion approaches this issue appears to be problematic.

11 Simon Maimela (Maimela 1985, p. 71) seems to have addressed this issue when he noted that for many Africans "the church is not interested in their daily misfortunes, illness, encounter with evil and witchcraft, bad luck, poverty, barrennessin short, all their concrete social problems [ ... ]. Most Africans often do not know what to do with their new, attractive Christian religion and yet one which dismally fails to meet their emotional and spiritual needs". He also framed this as the strength of AICs-they give Africans "an open invitation to bring concrete social problems to the church leadership". 
As suggested by Jarvis (2009, p. 43), the only possible way in which Africans may fully become Christians is when they renounce their cultural and religious beliefs, which conflict with the revelation of God as found in the Bible. In this regard, one cannot be a devout Christian while holding to their traditional culture and religious beliefs. This argument seems to speak directly to the concern of this paper. How are Africans to measure and extract those cultural and religious beliefs that stands against the word of God, when their cultural and religious elements are intertwined? Does not this, ultimately, lead towards the abandonment of the entire African heritage? For that matter, how can Africans attain a sense of ignorance (or lack of fear) for the reality of evil spirits, evil spells, curses, or the anger or favour of spirits of ancestors, when that is an integral part of their lived experiences? ${ }^{12}$

However, scholars like Mbiti (1975, p. 130), and Leonard (1906, p. 429) have shown that the total break away of Africans from their cultural roots and religious beliefs is almost an impossible mission. This is because the traditional culture and religious beliefs of Africans form part of their identity. Leonard (1906) expressed this sentiment in the following manner: "The religion of these natives (Africans) is their existence and their existence is their religion [...]. The entire organisation of their common life is so interwoven with it that they cannot get away from it [...]" (Leonard 1906, p. 429).

Some sixty-nine years later, Mbiti (1975) observed a similar attitude regarding the total break away of Africans from their traditional culture and religious beliefs:

[W] hen Africans migrate in large numbers from one part of the continent to another, or from Africa to other continents, they take religion with them. They can only know how to live within their religious context. Even if they are converted to another religion like Christianity or Islam, they do not completely abandon their traditional religion immediately: it remains with them for several generations and sometimes centuries. (Mbiti 1975, p. 13)

It therefore appears to be difficult for Africans to entirely abandon their traditional culture and religious beliefs. Even if they do eventually abandon these, it is a process that takes several generations, and sometimes centuries. Their new Christian identity is often adopted in conjunction with the old African traditional and religious identity. As Mbiti $(1975$, p. 13) contended, this is because their African religion is their way of life and "within that religious way of life, they know who they are, how to act in different situations, and how to solve their problems". The act of asking Africans to renounce their cultural and religious beliefs in order to be Christians therefore, seems to be a huge ask on the part of conservative Christianity.

The African rigorist perspective, as well, appears to pose some problems. It seems to suggest that one cannot freely experience their 'true' African spirituality when they amalgamate the ATR with other faiths like Christianity (Mndende 2009, p. 1). The expression of 'true' African spirituality appears to come only when indigenous people continue to preserve their African cultural and religious heritage which was handed down to them by the forebears of the present generation. In this manner, one cannot embrace the ATR together with other religions because this denotes that they are "sitting on the fence" (Mndende 2009, p. 1).

The supposed contradiction of embracing the ATR together with Christianity is remarked upon by Mndende (2009) as follows:

One wonders how one can officiate in a ritual professing ancestors as intermediaries between humanity and God, and at the same time go to church and preach that Jesus is the way, the truth and the life? Surely these two practices are based on mutually exclusive, irreconcilable tenets of faith; a contradiction in terms. (Mndende 2009, p. 8)

Thus, the African rigorist perspective argues that one cannot be an African religionist while a Christian at the same time. This perspective however, seems to overlook the reality of people who

12 For further discussions on this matter (cf. Anderson 2000, pp. 30-31). 
amalgamate the two systems-Christianity and ATR, and hold that they are related systems of thought and practice. It is a known fact that there are Africans who regard themselves as Christians while they are also traditional healers, or continue to practice their traditional customs (Mlisa 2009, p. 8; Hirst 2005, p. 4). This African rigorist view seems to undermine the existence of such a reality. This view further seems to suggest that converting to Christianity, as Mbiti $(1975$, p. 13) and Leonard (1906, p. 429) argued, is almost impossible because Africans find it difficult to renounce their traditional cultures and religious beliefs.

Leonard (1906, p. 429) seem to have endorsed this sentiment when he pointed out that Africans can only freely express themselves within their religious context: "[T]hey eat religiously, drink religiously, and sing religiously". In this regard, the religion of Africans is said to be an overarching factor that is intimately interwoven to their cultural expressions, from which no other religion can replace. In this form of expression, Africans are said to "eat religiously, drink religiously and (even) sing religiously" (Leonard 1906, p. 429). Even though this may possess some truth, it is not always the case. Jarvis (2009, p. 34) notes that there are Africans who converted to Christianity, that have completely broken away from the influence of their cultures and religious beliefs-particularly from the influence of venerating ancestors.

The last perspective, which assumes the middle ground, seems to address the realism of Africans who live with the awareness of the influence of Christianity on the ATR, and also acknowledge the impact exerted by the ATR on Christianity. On the one hand, there are African religionists who argue that Christianity has strongly influenced Africans so much that they had to incorporate Christian values into their cultural systems (Mlisa 2009, p. 9). On the other hand, there are Christians who argue that Christianity cannot be expressed or communicated outside a cultural medium and therefore the African cultural heritage must give context to the expression of Christianity (Mugambi 2002, p. 519).

The separation of Christianity from the African culture, in this perspective, is said to have resulted in a life of double standards among African converts (Pityana 1999, p. 137; Mtuze 2003, p. 8). This view, therefore, maintains that Christianity must find an expression within the cultural context. In this backdrop, where the terms of one religion are expressed through the other, Mugambi (2002, p. 518) notes that "[s]cholars are now predicting that in the twenty-first century Christianity will be riding on the cultures of Africa and Asia". Therefore, this seems to suggest that the expression of Christianity within the African cultural context is the only realistic premise for African Christianity.

This perspective however, seems to raise a number of concerns. The first is that the practices of both Christianity and ATR appear to be contradictory. Mndende $(2009$, p. 8), for instance, argues that one cannot simply officiate in a ritual that profess ancestors as mediators between humanity and God, and then turn to preach that Jesus is the way, the truth and the life. Therefore, the practices of these two systems are "based on mutually exclusive, irreconcilable tenets of faith; a contradiction in terms" (Mndende 2009, p. 8).

The second concern is that there are no definite boundaries between the plain elements of the African cultural and religious heritage (Mndende 2009, p. 117). Both the elements of the African cultural heritage and religious heritage are seen as overlapping, and thus are often thought of as an item. In this overlap, there is no distinction between traditional customs and religious beliefs. One can therefore not identify the cultural heritage from the religious life of Africans. Due to this limitation, the calling of traditional healers is often perceived as part of the African cultural heritage, instead of being looked at, only, as the aspect of the African religious life ${ }^{13}$.

As the integral part of the African cultural heritage, divination is principally accepted on the bases, and explained in terms of one's cultural lineage-in terms of Xhosa divination, Zulu divination, or any other African agnatic groups' system of divination (Hirst 2007, pp. 218-19). In this context,

13 Nokuzola Mndende (Mndende 2013, p. 78) exemplifies this intersection when she states that "rituals are special gatherings of the clans aimed at communal religious practices". This means that some agnatic group rituals carry a religious significance, even though they are taken as communal. 
the connection of one with their clan is imperative; as the call to divination is transmitted, or may be responded to wholly within one's agnatic group (Hirst 2005, p. 3). This call is said to come from the ancestors (Mlisa 2009, p. xii). The ancestors are deceased senior males of the agnatic group or clan, who are the descendants of the common great-grandfather (Hammond-Tooke 1974, pp. 17-19) ${ }^{14}$. But in the Mpondo tradition, the concept of ancestors also includes all the deceased old people, and not just the deceased senior males (Hunter 1936, p. 123).

Because ancestors play a significant role in African cosmology, their status has often been overly elevated (Muzorewa 1985, p. 12). Some Christians go so far as to equate Jesus Christ with ancestors (Nxumalo 1981, p. 67) ${ }^{15}$. According to Nyamiti $(1984$, p. 9), this is a paradigm which begins with "African ancestral beliefs and practices and tries to confront these with the Christian teaching on the saviour". African theologians such as Charles Wanamaker (Wanamaker 1997, p. 296) Kwame Bediako (Bediako 1994, p. 99), and Francois Kabasele (Kabasele 1991, p. 46) seem to advocate for this Christology. However, scholars such as Jarvis (2009, pp. 25-27) have been very critical of the elevation of ancestors. He maintains that "it is God who should be held in awe, not the spirits of the ancestors, or any other spirit" (Jarvis 2009, p. 43). Because ancestors form part of the African cultural and religious heritage, their role and position within the African cultural setting, and Christian church (AICs) will always be an open-ended discussion-They seem to connect Africans to their cultural and religious heritage.

Therefore, due to the prevalence of these variant perspectives, the status of Christians who amalgamate Christianity with ATR remains a heated debate in South Africa. As a result, many Africans have resolved to live by double standards, professing to be Christians in public, while reverting to the practice of ATR in private (Ntombana 2015, p. 105). This is a phenomenon which scholars like Mbiti (1992, p. 264) describe as "religious concubinage". It is a phenomenon whereby believers acknowledge one religion in public while they practice another in private. Mathema $(2007$, p. 5) contends that these are professed Christians who derive some form of satisfaction from African traditional practices.

The contextualization of Christianity in Africa therefore, is undoubtedly a necessary venture. Christianity needs to communicate with the African cultural and religious heritage. This means that it needs to be couched in a language that Africans can understand and appreciate, and further be presented in a manner that does not require the alienation of Africans from their cultural heritage. But in that endeavour, all aspects of the African cultural and religious heritage must be considered, not only the positive and negatives. These include the pragmatic nature of the African cultural and religious heritage, as well as the methods that Africans use to respond to moments of crises. Perhaps, the consideration of these may pave a way towards the exploration of methods in which Africans may be assisted in becoming genuine Christians without falling back to African traditional practices, or having to rely on traditional interventions for pressing issues.

Again, this consideration may require the exploration of the viability of traditional methods of healing - that is, which traditional remedies are to be acceptable or non-acceptable; which should be considered harmless or harmful against the Christian faith; and which traditional remedies, to some extent, can be tolerated or incorporated into the Christian system. Of course, this discussion may have to consider and critically evaluate the role of traditional healers, herbalists or seers as collaborators in the administration of traditional remedies, which I suppose may not be an easy task to undertake. But the role of traditional healers, herbalists or seers cannot be taken for granted. They are the primary givers of traditional remedies, which promise immediate returns. Perhaps the consideration of these

14 For further discussions (cf. Mayer and Mayer 1974, p. 151; Wilson 1982, p. 27).

15 Jabulani Nxumalo (Nxumalo 1981, p. 67) asserts the following: "In my view, there is a relationship between Christ and the ancestors, for the simple reason that Christ died too. He is therefore an idlozi (the living-dead) to us, since those who are dead are amadlozi (plural of idlozi) for us. Therefore Christ and those who have died are united together. We call them together in Christ". 
"things in between" may provide the necessary clarity on how Christianity can best be expressed and practiced within the African cultural and religious heritage.

Conflicts of Interest: The author declares no conflict of interest.

\section{References}

Adamo, David T. 2011. Christianity and the African Traditional Religion(s): The Postcolonial Round of Engagement. Verbum et Ecclesia 32: 1-10. [CrossRef]

Akao, John O. 2002. The Task of African Theology: Problems and Suggestions. Scriptura 81: 341-43. [CrossRef]

Amanze, James N. 2003. Christianity and Ancestor Veneration in Botswana. Studies in World Christianity 8: 43-49. [CrossRef]

Anderson, Allan. 2000. Zion and Pentecost: The Spirituality and Experience of Pentecostal and Zionist/Apostolic Churches in South Africa. Pretoria: Unisa Press.

Awolalu, Omosade J., and Adelumo P. Dopomu. 1979. West African Traditional Religion. Ibadan: Onibonoje Press \& Book Industries.

Awolalu, Omosade J. 1976. Sin and its Removal in African Traditional Religion. Journal of the American Academy of Religion 44: 275-87. [CrossRef]

Barker, Gregory A. 2005. Christianity: A Guide to Christianity. Oxford: The Subject Centre for Philosophical and Religious Studies.

Bediako, Kwame. 1992. Theology and Identity: The Impact of Culture upon Christian Thought in the Second Century and Modern Africa. Oxford: Regnum Books International.

Bediako, Kwame. 1994. Understanding African Theology in the 20th Century. Themelios 20: 14-20.

Bosch, David J. 1991. Transforming Mission: Paradigm Shifts in Mission Theology. Maryknoll: Orbis Books.

Bujo, Bénézet. 2003. Foundations of an African Ethic: Beyond the Universal Claims of Western Morality. Nairobi: Paulines Publications Africa.

Buthelezi, Manas. 1986. Toward Indigenous Theology in South Africa. In Third World Liberation Theologies: A Reader. Edited by Dean W. Ferm. Maryknoll: Orbis Books, pp. 205-21.

Carson, Donald A. 2015. On Disputable Matters. Themelios 40: 383-88.

Crafford, Dionne. 2015. African Traditional Religions. In South Africa, Land of Many Religions. Edited by Arno Meiring and Piet Meiring. Wellington: Christian Literature Fund.

Evans, Richard G. 2009. Sancta Indifferentia and Adiaphora: "Holy Indifference" and "Things Indifferent". Common Knowledge 15: 23-38. [CrossRef]

Fasholé-Luke, Edward W. 1975. The Quest for an African Christian Theology. The Ecumenical Review 27: 267. [CrossRef]

Fiedler, Klaus. 1996. Christianity and African Culture: Conservative German Protestant Missionaries in Tanzania, 1900-1940. Leiden and Boston: E. J. Brill.

Futhwa, Fezekile. 2011. Sesotho Afrikan Thought and Belief Systems. Alberton: Nalane Publication.

Hammond-Tooke, David W. 1974. The Bantu-Speaking Peoples of Southern Africa. London: Routledge \& Kegan Paul Publication.

Hastings, Adrian. 1989. African Catholicism-An Essay in Discovery. London: SCM Press.

Hirst, Manton M. 2005. Dreams and Medicines: The Perspective of Xhosa Diviners and Novices in the Eastern Cape, South Africa. Indo-Pacific Journal of Phenomenology 5: 1-22. [CrossRef]

Hirst, Manton M. 2007. A River of Metaphors: Interpreting the Xhosa diviner's myth. Journal of African Studies 56: 217-50. [CrossRef]

Hunter, Monica. 1936. Reaction to Conquest: Effects of Contact with Europeans on the Pondo of South Africa. Oxford: Oxford University Press.

Idowu, Bolaji E. 1973. African Traditional Religion: A Definition. London: SCM Press.

Isichei, Elizabeth. 1995. A History of Christianity in Africa: From Antiquity to the Present. Grand Rapids: William B. Eerdmans Publishing Company.

Jarvis, Michael. 2009. Ubuntu Christianity. Wellington: Fact and Faith Publications.

Jebadu, Alexander. 2007. Ancestral Veneration and the Possibility of its Incorporation into the Christian Faith. Exchange 36: 246-80. [CrossRef] 
Kabasele, Francois L. 1991. Christ as Ancestor and Elder Brother. In Faces of Jesus in Africa. Edited by Robert J. Schreiter. New York City: Orbis Books, pp. 116-27.

Lado, Ludovic. 2006. The Roman Catholic Church and African Religions: A problematic encounter. The Way 45: $7-21$.

Leonard, Arthur G. 1906. The Lower Niger and It's Tribes. London: Macmillan and Company, Ltd.

Magesa, Laurenti. 1998. African Religion: The Moral Traditions of Abundant Life. Nairobi: Paulines Publications Africa.

Magesa, Laurenti. 2004. Anatomy of Inculturation: Transforming the Church in Africa. Maryknoll: Orbis Books.

Maimela, Simon S. 1985. Salvation in African Traditional Religion. Missionalia 13: 63-77.

Maluleke, Tinyiko S. 2005. Half a Century of African Christian Theologies: Elements of the Emerging Agenda for the Twenty-First Century. In African Christianity: An African Story. Edited by Ogbu. U. Kalu. Pretoria: University of Pretoria, pp. 469-93.

Maluleke, Tinyiko S. 2010. Africanised Bees and Africanised Churches: Ten Theses on African Christianity. Missionalia: Southern African Journal of Mission Studies 38: 369-79.

Mathema, Zacchaeus A. 2007. The African Worldview: A Serious Challenge to Christian discipleship. Ministry, International Journal for Pastors 79: 5-7.

Matobo, Thope A., M. Makatsa, and Emeka E. Obioha. 2009. Continuity in the Traditional Initiation Practice of Boys and Girls in Contemporary Southern African Society. Studies of Tribes and Tribals 7: 105-13. [CrossRef]

Mayer, Philip, and Iona Mayer. 1974. Townsmen or Tribesmen: Conservation and the Process of Urbanization in a South African City. Cape Town: Oxford University Press.

Mbiti, John S. 1969. African Religions and Philosophy. London: Heinemann Educational Publishers.

Mbiti, John S. 1975. Introduction to African Religion. London: Heinemann Educational Books.

Mbiti, John S. 1977. The Biblical Basis for Present Trends in African Theology. In African Theology en Route: Papers from the Pan-African Conference of Third World Theologians, Accra, December 17-23 1977. Edited by Kofi Appiah-Kubi and Sergio Torres. Maryknoll: Orbis Books, pp. 83-94.

Mbiti, John S. 1990. African Religions and Philosophy. Oxford: Heinemann International.

Mbiti, John S. 1992. African Religions and Philosophy, 2nd ed. revised; London: Heinemann Educational Books.

McGuire, Meredith B. 2008. Lived Religion: Faith and Practice in Everyday Life. Oxford: Oxford University Press.

Mills, Wallace G. 1995. Missionaries, Xhosa Clergy and the Suppression of Traditional Customs. In Missions and Christianity in South African History. Edited by Henry C. Bredenkamp and Robert J. Ross. Johannesburg: Witwatersrand University Press, pp. 153-72.

Mlisa, Nomfundo L. 2009. Ukuthwasa, the Training of Xhosa Women as Traditional Healers. Ph.D. Thesis, University of the Free State, Bloemfontein, South Africa.

Mndende, Nokuzola. 2009. Tears of Distress: Voices of a Denied Spirituality in a Democratic South Africa. Dutywa: Icamagu Institute.

Mndende, Nokuzola. 2013. Law and Religion in South Africa: An African Traditional Perspective. Nederduitse Gereformeerde Teologiese Tydskrif 54: 74-82. [CrossRef]

Mogoba, Mmutlanyane S. 2011. The Religious Background to African Christianity: African Traditional Religion. In The Journey of Hope: Essays in Honour of Dr Mmutlanyane Stanley Mogoba. Edited by Itumeleng Mekoa. Cape Town: The Incwadi Press, pp. 170-85.

Mokhoathi, Joel. 2017. Imperialism and its effects on the African Traditional Religion: Towards the liberty of African Spirituality. Pharos Journal of Theology 98: 1-15.

Motlhabi, Mokgethi G. 1994. Black or African Theology? Towards an Integral African Theology. Journal of Black Theology in South Africa 8: 113-41.

Mtuze, Peter T. 2003. The Essene of Xhosa Spirituality: And the Nuisance of Cultural Imperialism: Hidden Presences in the Spirituality of the annaXhosa of the Eastern Cape and the Impact of Christianity on Them. Florida Hills: Vivlia Publishers and Booksellers.

Mugambi, Jesse N. K. 1995. From Liberation to Reconstruction: African Christian Theology after the Cold War. Nairobi: East African Educational Publishers.

Mugambi, Jesse N. K. 2002. Christianity and the African Cultural Heritage. In Christianity and African Culture. Edited by Jesse. N. K. Mugambi. Nairobi: Acton Publications, pp. 516-42.

Muzorewa, Gwinyai. H. 1985. The Origins and Development of African Theology. Maryknoll: Orbis Books. 
Ntombana, Luvuyo. 2015. The Trajectories of Christianity and African Ritual Practices: The Public Silence and the Dilemma of Mainline or Mission Churches. Acta Theologica 35: 104-19. [CrossRef]

Nwibo, Joseph. 2010. A Brief Note on the Need for African Christian Theology. Paper presented at the Cursus Godsdient Onderwijs (CGO-HBO), Lienden, The Netherlands, September 22.

Nxumalo, Jabulani A. 1981. Zulu Christians and Ancestor Cult: A Pastoral Consideration. In Ancestor Religion in Southern Africa. Edited by Heinz Kuckertz. Transkei: Lumko Missiological Institute, pp. 65-78.

Nyamiti, Charles. 1984. Christ as Our Ancestor: Christology from an African Perspective. Gweru: Mambo Press.

Oden, Thomas C. 2007. How Africa Shaped the Christian Mind: Rediscovering the African Seedbed of Western Christianity. Westmont: InterVarsity Press Books.

Oduro, Thomas, Hennie Pretorius, Stan Nussbaum, and Bryan Born. 2008. Mission in an African Way: A Practical Introduction to African Instituted Churches and Their Sense of Mission. Wellington: Christian Literature Fund and Bible Media Publication.

Onuzulike, Uchenna. 2008. African Crossroads: Conflicts between African Traditional Religion and Christianity. The International Journal of the Humanities 6: 163-69. [CrossRef]

Pityana, Nyameko B. 1999. The Renewal of African Moral Values. In African Renaissance: The New Struggle. Edited by William M. Makgoba. Sandton: Mafube Publishing, pp. 137-48.

Richter, Marlise. 2003. Traditional Medicines and Traditional Healers in South Africa. Discussion Paper Prepared for the Treatment Action Campaign and AIDS Law Project. Available online: http://www.tac.org.za/ Documents/ResearchPapers/Traditional_Medicine_briefing.pdf (accessed on 29 November 2017).

Sanou, Boubakar. 2013. Missiological Perspectives on the Communal Significance of Rites of Passages in African Traditional Religions. Journal of Adventist Mission Studies 9: 39-52.

Shaw, Rosalind, and Charles Stewart. 1994. Introduction: Problematizing syncretism. In Syncretism/Anti-Syncretism: The Politics of Religious Synthesis. Edited by Charles Stewart and Rosalind Shaw. London: Routledge Press, pp. 1-26.

Shorter, Aylward. 1975. African Christian Theology: Adaptation or incarnation? Michigan: Geoffrey Chapman.

Southern African Catholic Bishops. 2006. Ancestor Religion and the Christian Faith. Paper presented at Resolution 2.5.2 of the Plenary Session of the Southern African Catholic Bishops' Conference, Mariannhill, KwaZulu Natal, South Africa, August 11.

Stewart, Charles. 1994. Syncretism as a Dimension of National Discourse in Modern Greece. In Syncretism/Anti-Syncretism: The Politics of Religious Synthesis. Edited by Charles Stewart and Rosalind Shaw. London: Routledge Press, pp. 127-44.

The New Encyclopaedia Britannica. 2007. Mainstream Christianity: Definition. Chicago: Encyclopaedia Britannica, Inc. Truter, IIse. 2007. African Traditional Healers: Cultural and Religious Beliefs Intertwined in a Holistic Way. SA Pharmaceutical Journal 74: 56-60.

Tutu, Desmond. 1986. Black Theology and African Theology: Soulmates or Antagonists? In Third World Liberation Theologies: A Reader. Edited by Dean W. Ferm. Maryknoll: Orbis Books, pp. 256-64.

Van der Merwe, Dirk. 2016. From Christianising Africa to Africanising Christianity: Some hermeneutical principles. Stellenbosch Theological Journal 2: 559-87.

Wanamaker, Charles A. 1997. Jesus the Ancestor: Reading the Story of Jesus from an African Christian Perspective. Scriptura 62: 281-98. [CrossRef]

Wilson, Monica. 1982. The Nguni People. In A History of South Africa to 1870. Edited by Monica Wilson and Leonard Thompson. Cape Town: David Philip Publication, pp. 75-130.

(C) 2017 by the author. Licensee MDPI, Basel, Switzerland. This article is an open access article distributed under the terms and conditions of the Creative Commons Attribution (CC BY) license (http://creativecommons.org/licenses/by/4.0/). 